\title{
PENGARUH DIAMETER FILLER DAN ARUS PADA PENGELASAN TIG TERHADAP KEKUATAN TARIK DAN STRUKTUR MIKRO PADA BAJA KARBON RENDAH
}

\author{
Eko Budiyanto $^{1^{\star}}$, Eko Nugroho², Achmad Masruri ${ }^{3}$ \\ Jurusan Teknik Mesin, Fakultas Teknik, Universitas Muhammadiyah Metro ${ }^{1,2,3}$ \\ Jl. Ki Hajar Dewantara 15 A Metro, Lampung \\ e-mail ; eko_budiyanto99@yahoo.com¹, exonugros@gmail.com², \\ achmadmasruri123@yahoo.com ${ }^{3}$
}

\begin{abstract}
Abstrak
Terdapat berbagai jenis pengelasan yang dapat digunakan dalam proses penyambungan logam, salah satunya adalah TIG (Tungsten Inert Gas). TIG yang juga biasa disebut GTAW (Gas Tungsten Arc Welding) adalah jenis pengelasan yang menggunakan panas dari nyala pijar yang terbentuk antara elektroda tungsten yang tidak terumpan dengan menggunakan gas mulia sebagai pelindung terhadap pengaruh luar pada saat proses pengelasan. Elektroda las menggunakan batang wolfram yang dapat menghasilkan busur listrik tanpa ikut mencair. Tujuan penelitian ini adalah untuk mengetahui pengaruh variasi arus dan diameter filler (kawat las) terhadap pengelasan baja karbon rendah. Penelitian ini mengunakan las TIG dengan filler jenis ER 309L berdiameter 1,2 mm, 1,6 mm, 2,0 mm dan 2,4 mm. Bahan yang akan dilas adalah bahan baja karbon rendah dengan kuat tarik bahan sebesar $36,37 \mathrm{kgf} / \mathrm{mm}^{2}$. Saat proses pengelasan, kuat arus yang yang divariasikan dengan filler adalah 80A, 100A dan 120A. Kampuh yang dipakai adalah jenis kampuh V dengan sudut $90^{\circ}$. Untuk mengetahui pengaruh dari perlakuan tersebut, spesimen pengelasan dilakukan pengujian tarik dan foto stuktur mikro. Kuat tarik sambungan las tertinggi ditunjukkan pada pengelasan yang menggunakan filler berdiamater 1,6 $\mathrm{mm}$ dengan kuat arus 120 A dengan kuat tarik sambungan sebesar $41,74 \mathrm{kgf} / \mathrm{mm}^{2}$. Kuat tarik terendah didapatkan pada pengelasan yang menggunakan diameter filler $2,0 \mathrm{~mm}$ sebesar $39,71 \mathrm{kgf} / \mathrm{mm}^{2}$ dengan mengunakan kuat arus 120A. Pengamatan struktur mikro difokuskan pada daerah HAZ (Heat Affected Zone). Pada spesimen pengelasan yang mengunakan diameter filler 1,6 mm dengan variasi kuat arus sebesar 80A, 100A dan $120 \mathrm{~A}$. Terjadi peningkatan jumlah butiran ferit dan mengecilnya butiran ferit di daerah HAZ pada setiap kenaikan arus dalam pengelasan.
\end{abstract}

Kata kunci: Baja karbon rendah, Filler, HAZ, Kuat Arus, TIG.

\section{Pendahuluan}

Dengan semakin meningkatnya perkembangan industri manufaktur yang terjadi pada saat ini, maka banyak industri manufaktur yang menggunakan pengelasan dalam proses produksinya. Terdapat berbagai jenis pengelasan yang digunakan, salah satunya adalah TIG (Tungsten Inert Gas). TIG atau disebut juga GTAW (Gas Tungsten Arc Welding) adalah jenis pengelasan yang menggunakan panas dari nyala pijar yang terbentuk antara elektroda tungsten yang tidak terumpan dengan menggunakan gas mulia sebagai pelindung terhadap pengaruh luar pada saat proses pengelasan. Elektroda las menggunakan batang wolfram yang dapat menghasilkan busur listrik tanpa ikut mencair. Pada penggunaan las TIG, kecepatan pengumpanan logam pengisi dapat diatur terlepas dari besarnya arus listrik sehingga terjadi penetrasi ke dalam logam induk. Cara pengaturan ini memungkinkan las TIG cocok digunakan pada pelat baja tipis maupun pelat baja tebal.

Penelitian terdahulu mengungkap tentang pengaruh penggunaan variasi 
besaran arus pada las TIG terhadap perubahan struktur mikro. Hasil yang diperoleh adalah semakin tinggi arus maka semakin tinggi tegangan luluhnya dan tegangan maksimumnya, hal ini menunjukkan peningkatan sifat mekanis pada logam apabila pengelasan dilakukan dengan arus lebih tinggi [1]. Penelitian berikutnya adalah tentang pengaruh proses pengelasan TIG terhadap sifat mekanis bahan paduan Alumunium, hasil yang diperoleh adalah kekuatan tarik material aluminium mengalami penurunan pada daerah sambungan [2].

Tujuan dari penelitian ini adalah untuk mengetahui pengaruh diameter filler dan besaran arus pada las TIG terhadap sifat fisik-mekanik hasil pengelasan baja karbon sedang. Sifat mekanik yang diteliti adalah kekuatan tarik, sedangkan sifat fisik yang diteliti adalah struktur mikro yang terbentuk pada masing-masing daerah logam induk, daerah HAZ, daerah batas las, dan daerah lasan.

\section{Tinjauan Teoritis}

\section{Pengelasan}

Pengelasan (welding) adalah proses penyambungan dua buah logam atau lebih dengan mengunakan proses pemanasan setempat sehinnga terjadi ikatan metalurgi antara logam-logam yang di sambung. Proses penyambungan logam banyak digunakan pada industri untuk pekerjaan kontruksi, pembuatan mesin, peralatan pabrik, kontruksi pemipaan, serta pengerjaan lain yang memerlukan sambungan. Proses difusi dalam sambungan las dapat dilakukan dengan kondisi padat maupun cair.

Dalam terminologi las, kondisi padat disebut Solid State Welding (SSW) atau Presure welding dan kondisi cair disebut Liquid state welding (LSW) atau Fusion welding [3].

Proses SSW biasanya dilakukan dengan tekanan sehingga proses ini disebut Presure welding. Proses SSW memiliki beberapa kelebihan, diantaranya adalah dapat menyambung dua buah material atau lebih yang tidak sama, proses cepat, presisi, dan hampir tidak memiliki daerah HAZ. SSW mempunyai kelemahan yaitu persiapan sambungan dan prosesnya rumit, sehingga dibutuhkan ketelitian yang sangat tinggi.

Pada proses las LSW, sambungan las terjadi karena adanya pencairan ujung kedua material yang disambung. Energi panas yang digunakan untuk mencairkan material berasal dari busur listrik, tahanan listrik, pembakaran gas, dan juga beberapa cara lain diantaranya adalah sinar laser, sinar elektron, dan busur plasma. Penyambungan material dengan cara ini mempunyai persyaratan material harus sama, karena untuk mendapatkan sambungan yang sempurna suhu material harus sama. Jika material yang disambung jenisnya berbeda, proses penyambungan tidak dapat terjadi. Kelebihan metode pengelasan LSW adalah proses dan persiapan sambungan tidak rumit, biaya murah, dan pelaksanaannya mudah. Kelemahannya adalah memerlukan juru las yang terampil serta terjadinya HAZ yang menyebabkan perubahan sifat bahan, dan ada potensi kecelakaan dan terganggunya kesehatan juru las.

Tabel 1. Kode proses las Bedasarkan ISO

\begin{tabular}{|c|c|c|c|c|c|}
\hline & & & & $\begin{array}{c}\text { Jenis } \\
\text { Proses Las }\end{array}$ & $\begin{array}{l}\text { Kode } \\
\text { ISO }\end{array}$ \\
\hline \multirow{17}{*}{$\begin{array}{l}\text { WELDING } \\
\text { PROCESSES }\end{array}$} & \multirow{12}{*}{$\begin{array}{l}\text { LIQUID STATE } \\
\text { WELDING }\end{array}$} & \multirow{8}{*}{$\begin{array}{l}\text { Electric Arc } \\
\text { Welding }\end{array}$} & Flash Butt & Stud Welding & 781 \\
\hline & & & Flash Butt & $\begin{array}{l}\text { Projection } \\
\text { Welding }\end{array}$ & \\
\hline & & & $\begin{array}{l}\text { Consumable } \\
\text { Electrode }\end{array}$ & $\begin{array}{l}\text { Shelded Metal } \\
\text { Arc Welding } \\
\text { (SMAW) }\end{array}$ & 111 \\
\hline & & & $\begin{array}{l}\text { Consumble } \\
\text { Electrode }\end{array}$ & $\begin{array}{l}\text { Metal Irent Gas } \\
\text { Weldirg (MIG) }\end{array}$ & 131 \\
\hline & & & $\begin{array}{l}\text { Consumable } \\
\text { Electrode }\end{array}$ & $\begin{array}{l}\text { Metal Active Gas } \\
\text { Welding (MAG) }\end{array}$ & 135 \\
\hline & & & $\begin{array}{l}\text { Consumable } \\
\text { Electrode }\end{array}$ & $\begin{array}{l}\text { Flux Coned Avc } \\
\text { Welding (FCAW) }\end{array}$ & 114 \\
\hline & & & $\begin{array}{l}\text { Non } \\
\text { Consumable }\end{array}$ & $\begin{array}{l}\text { Tungsten inert } \\
\text { Gas (TTG) }\end{array}$ & 141 \\
\hline & & & $\begin{array}{l}\text { Non } \\
\text { Consumable }\end{array}$ & $\begin{array}{l}\text { Plasma Arc } \\
\text { Welding (PAM) }\end{array}$ & 15 \\
\hline & & \multicolumn{2}{|c|}{ Resistance Welding } & Spot Welding & \\
\hline & & \multicolumn{2}{|c|}{ Resistance Welding } & Seam Weldirg & \\
\hline & & \multicolumn{2}{|c|}{ Thermal Welding } & Gas Welding & 3 \\
\hline & & \multicolumn{2}{|c|}{ Thermal Welding } & Laser Weldirng & - \\
\hline & \multirow{5}{*}{$\begin{array}{c}\text { SOLID STATE } \\
\text { WELDING }\end{array}$} & \multicolumn{3}{|c|}{ Friction Welding } & 42 \\
\hline & & \multicolumn{2}{|c|}{ Cold Welding } & $\begin{array}{l}\text { Explosine } \\
\text { Welding }\end{array}$ & 441 \\
\hline & & \multicolumn{2}{|c|}{ Cold Welding } & $\begin{array}{l}\text { Ultrasonic } \\
\text { Weldirg }\end{array}$ & 41 \\
\hline & & \multicolumn{3}{|c|}{ Forge Welding } & 43 \\
\hline & & \multicolumn{3}{|c|}{ Diffusion Welding } & 45 \\
\hline
\end{tabular}




\section{Las TIG}

Las TIG (Tungsten Inert Gas) adalah proses pengelasan dimana busur nyala listik ditimbulkan oleh elektroda tungsten (elektroda tidak terumpan) dengan benda kerja logam [4]. Las listrik TIG menggunakan elektroda wolfram yang bukan merupakan bahan tambah. Busur listrik yang terjadi antara ujung elektroda wolfram dan bahan dasar merupakan sumber panas untuk pengelasan. Titik cair elektroda wolfram sedemikian tingginya sampai $3410^{\circ} \mathrm{C}$, sehingga tidak ikut mencair pada saat terjadi busur listrik. Tangkai listrik dilengkapi dengan nosel keramik untuk penyembur gas pelindung yang melindungi daerah las dari luar pada saat pengelasan. Sumber listrik yang digunakan untuk pengelasan TIG dapat berupa listrik DC atau listrik AC. Elektroda yang digunakan terbuat dari Wolfram murni atau paduan antara Wolfram - Torium, yang berbentuk batang dengan garis tengah antara $1,0 \mathrm{~mm}$ sampai $4,8 \mathrm{~mm}$. Gas yang dipakai untuk pelindung adalah gas Argon murni, karena pencampuran dengan $\mathrm{O}_{2}$ atau $\mathrm{CO}_{2}$ yang bersifat oksidator akan mempercepat keausan ujung elektroda. Sebagian bahan tambah dipakai elektroda selaput yang digerakkan dan didekatkan ke busur yang terjadi antara elektroda Wolffram dengan bahan dasar. Sebagian gas pelindung memakai angin, helium, atau campuran dari kedua gas tersebut yang pemakaiannya tergantung dari jenis logam yang akan di-las. Tangkai las TIG biasanya didinginkan dengan air bersikulasi.

Dalam pengelasan TIG standar, api dikeluarkan dengan bebas tetapi sebuah varian yang dikenal dengan pengelasan plasma menggunakan nozzle sekunder untuk mengecilkan arc. Lelehan logam, elektroda tungsten yang panas dan bagian ujung dari filler logam yang meleleh dilindungi dari atmosfir dengan menggunakan gas inert. Biasanya, menggunakan argon, meskipun ada manfaat kualitas dan produktivitas jika menggunakan campuran baik Argon dan Helium atauAargon dan Hidrogen. Perangkat yang dipakai dalam pengelasan las gas tungsten adalah:

1. Mesin las AC atau DC

2. Regulator gas lindung

3. Selang gas dan perlengkapannya

4. Elektroda tungsten

5. Gas pelindung

6. Kabel elektoda

7. Stang las (welding torch)

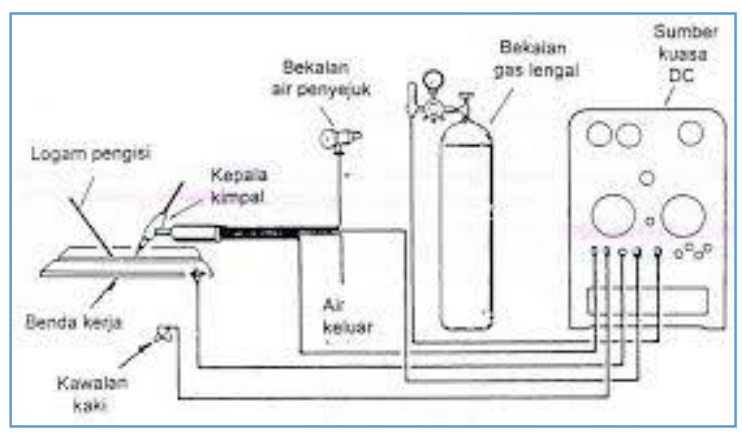

Gambar 1. Pengelasan TIG

\section{Elektroda tungsten}

Elektroda Tungsten adalah elektroda tak terumpan (non consumable electode) yang berfungsi sebagai pencipta busur nyala saja yang digunakan untuk mencairkan kawat las yang ditambah dari luar yang akan disambung menjadi satu kesatuan sambungan [4]. Elektroda Tungsten dibuat dari Tungsten sinter. Untuk memperbaiki sifat-sifatnya, dapat ditambah dengan oksida logam lain, pada umumnya thoriumoxid atau zirhoniumoxid. Elektroda Tungsten terdiri dari Elektroda Tungsten Murni dan Elektroda Tungsten Paduan. 
Tabel 2. Kode dan komposisi kimia elektroda Tungsten [5].

\begin{tabular}{|l|l|l|}
\hline \multicolumn{1}{|c|}{ Kode } & \multicolumn{1}{|c|}{ Paduan oksid dalam $\%$} & $\begin{array}{l}\text { Kode } \\
\text { Warna }\end{array}$ \\
\hline W & Tanpa paduan & Hijau \\
\hline WT 10 & $0,9 \ldots 1,2$ Thorium oksid & Kuning \\
\hline WT 20 & $1,8 \ldots 2,2$ Thorium oksid & Merah \\
\hline WT 30 & $2,8 \ldots 3,2$ Thorium oksid & Violet \\
\hline WT 40 & $3,8 \ldots 4,2$ Thorium oksid & Orange \\
\hline WZ 3 & $0,15 \ldots 0,5$ Zirkonium oksid & Coklat \\
\hline WZ 8 & $0,7 \ldots 0,9$ Zirkonium oksid & Putih \\
\hline WL 10 & $0,9 \ldots 1,2$ Lanthanium oksid & Hitam \\
\hline WL 20 & $\begin{array}{l}1.8 \ldots .2 .2 \% \text { Lanthanium } \\
\text { oksid }\end{array}$ & $\begin{array}{l}\text { Biru } \\
\text { Muda }\end{array}$ \\
\hline WC 20 & $1.8 \ldots .2 .2 \%$ Cherium oksid & $\begin{array}{l}\text { Abu- } \\
\text { Abu }\end{array}$ \\
\hline
\end{tabular}

\section{Bahan Tambah Las (Filler Rod)}

Merupakan logam pengisi kampuh las (filler metal) pada proses las GTAW atau TIG. Pemilihan bahan tambah TIG tergantung dari logam dasar (base metal) yang akan dilas. Filler rod dibuat dari logam yang komposisinya lebih unggul dibanding logam dasar. Mengingat dalam proses pengelasan ada beberapa unsur logam yang berkurang atau bertransformasi strukturnya sehingga berdampak pada pengurangan sifat-sifat mekanik logam. Sehingga filler metal harus dibuat komposisinya lebih unggul agar mampu mengatasi dampak-dampak tersebut diatas.

\section{Gas Pelindung Las TIG}

Pada las TIG yang paling umum / sering digunakan sebagai gas pelindungnya adalah gas Argon (Ar). Gas Argon dikenal karena kemurnian kimianya pada suhu yang tinggi. Argon, baik murni maupun mengandung sedikit karbon dioksida, oksigen, hidrogen dan helium, banyak dipergunakan sebagai gas pelindung dalam aplikasi pengelasan terhadap baja karbon dan stainless, aluminium, magnesium, dan sebagainya. Selain Argon, untuk pengelasan khusus bisa juga menggunakan Helium (He) atau campuran Argon-Helium.
Tabel 3. Gas Pelindung untuk Las TIG

\begin{tabular}{|c|c|c|}
\hline Gas & Bahan & Keterangan \\
\hline Argon & $\begin{array}{l}\text { Semua } \\
\text { Logam }\end{array}$ & $\begin{array}{l}\text { Lebih murah daripada } \\
\text { He }\end{array}$ \\
\hline Helium & $\begin{array}{l}\text { Semua } \\
\text { logam }\end{array}$ & $\begin{array}{l}\text { Arus searah } \\
\text { (Elektroda pada katup } \\
\text { negatif untuk } \\
\text { aluminium tipis) }\end{array}$ \\
\hline $\begin{array}{l}\text { Argon }+ \\
15 \div 75 \\
\% \\
\text { Helium }\end{array}$ & $\begin{array}{l}\text { Semua } \\
\text { logam }\end{array}$ & $\begin{array}{l}\text { Gas ini terutama } \\
\text { untuk las GTAW } \\
\text { mekanik penuh } \\
\text { (konvensional). } \\
\text { Dengan penambahan } \\
\text { He, mengurangi pori- } \\
\text { pori dan retak panas. } \\
\text { Memperkecil rigi-rigi } \\
\text { las } \\
\text { HAZ kecil } \\
\text { Penyalaan } \\
\text { memerlukan } \\
\text { tegangan tinggi }\end{array}$ \\
\hline $\begin{array}{l}\text { Argon }+ \\
\text { Max. } 7 \% \\
\mathrm{H} 2\end{array}$ & $\begin{array}{l}\text { Baja } \\
\text { kron - } \\
\text { nikel }\end{array}$ & $\begin{array}{l}\text { Mempertinggi } \\
\text { kecepatan las }\end{array}$ \\
\hline
\end{tabular}

\section{Metode Penelitian}

Variabel Penelitian

1. Variabel bebas : Arus pengelasan (80A, 100A, 120A) dan diameter filler $(1.2 \mathrm{~mm}, 1.6 \mathrm{~mm}, 2.0 \mathrm{~mm}$, dan 2.4 $\mathrm{mm})$.

2. Variabel terkontrol : jenis bahan dan ukuran spesimen, pengelasan TIG, jenis filler ER 309L, kecepatan pengelasan, jarak elektroda tehadap benda kerja.

3. Variabel terikat : kekuatan tarik dan struktur mikro.

Tabel 4. Variabel penelitian

\begin{tabular}{|c|c|c|c|}
\hline $\begin{array}{c}\text { Diameter } \\
\text { Filler }(\mathrm{mm})\end{array}$ & \multicolumn{3}{|c|}{ Arus } \\
\hline 1.2 & $80 \mathrm{~A}$ & $100 \mathrm{~A}$ & $120 \mathrm{~A}$ \\
\hline 1.6 & $80 \mathrm{~A}$ & $100 \mathrm{~A}$ & $120 \mathrm{~A}$ \\
\hline 2.0 & $80 \mathrm{~A}$ & $100 \mathrm{~A}$ & $120 \mathrm{~A}$ \\
\hline 2.4 & $80 \mathrm{~A}$ & $100 \mathrm{~A}$ & $120 \mathrm{~A}$ \\
\hline
\end{tabular}

Waktu penelitian

Penelitian ini dilaksanakan pada bulan Januari sampai dengan Juli 2016. 
Tempat penelitian

1. Pengelasan dan pembuatan spesimen : Laboratorium Teknik Mesin Universitas Muhammadiyah Metro, Lampung,

2. Pengujian uji tarik : B4T, Bandung, Jawa Barat,

3. Pengujian struktur mikro : UPT Balai Pengolahan Mineral Lampung-LIPI, Tanjung Bintang, Lampung Selatan.

Bahan

Plat baja karbon rendah ST 37 dengan ketebalan $3 \mathrm{~mm}$.

Alat

1. Mesin las TIG,

2. Elektroda las (AWS A5.12-80 EWT-2 $\varnothing 1.6)$,

3. Travo : Black Rihno HT- 160 A (DC Inverter MMA),

4. Gas pelindung (Argon),

5. Filer ER 309L dengan diameter $\varnothing 1.2 \mathrm{~mm}, \varnothing 1.6 \mathrm{~mm}, \varnothing 2.0 \mathrm{~mm}$ dan $\varnothing 2.4 \mathrm{~mm}$,

6. Alat pengukur kesudutan,

7. Alat bantu lainnya (gerinda, gergaji besi, amplas, palu, pengaris, spidol, kaca mata las, sarung tangan las).

Prosedur pengujian

1. Melakukan proses pengelasan

- Memotong spesimen dengan ukuran $350 \mathrm{~mm}, 30 \mathrm{~mm}$, dan $3 \mathrm{~mm}$ sebanyak 24 buah,

- Membuat kampuh V dengan sudut $90^{\circ}$, jarak kampuh $3 \mathrm{~mm}$,

- Menyesuaikan arus pengelasan (80A, 100A, dan 120A),

- Melakukan pengelasan spesimen mengunakan filler logam pengisi ER 309L dengan ukuran diameter $\emptyset 1.2 \mathrm{~mm}, \varnothing 1.6 \mathrm{~mm}, \emptyset 2.0 \mathrm{~mm}$, dan $\varnothing 2.4 \mathrm{~mm}$.

2. Melakukan uji tarik,

3. Melakukan pengamatan struktur mikro.

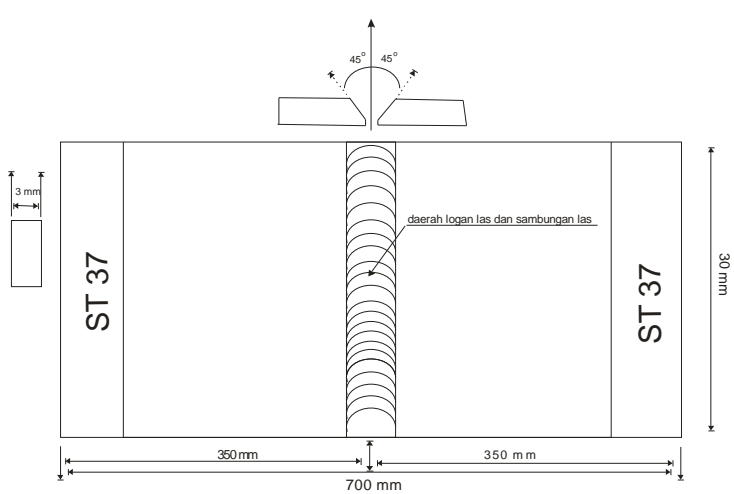

Gambar 2. Bentuk dan dimensi spesimen pengelasan

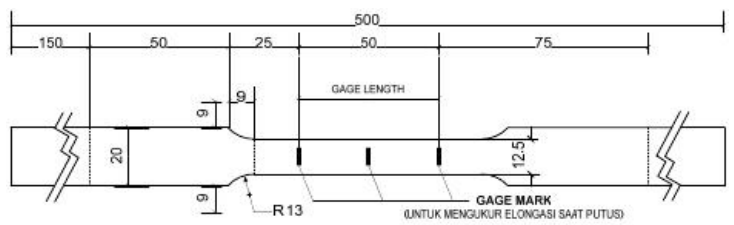

Gambar 3. Bentuk dan dimensi spesimen uji tarik

\section{Hasil dan Pembahasan}

Pengujian awal tegangan tarik bahan baja karbon rendah yang dipakai mengunakan ASTM A370-2012 (Standard Test Methods and Definitions for Mechanical Testing of Steel Products) dan diperoleh kuat tarik bahan sebesar 36,37 $\mathrm{kgf} / \mathrm{mm}^{2}$. Pengujian tarik hasil pengelasan mengunakan standarisasi ASME SECT IX2013(ASME BOILER AND PRESSURE VESSEL CODE).

Tabel 5. Data Hasil Uji Tarik hasil pengelasan (Diameter filler $\varnothing$ $1,2 \mathrm{~mm}$ )

\begin{tabular}{|c|c|c|c|}
\hline \multirow{2}{*}{$\begin{array}{l}\text { Kuat } \\
\text { Arus }\end{array}$} & \multicolumn{2}{|c|}{ Kuat tarik } & \multirow{2}{*}{$\begin{array}{c}\text { Rata - } \\
\text { rata } \\
\mathrm{kgf} / \mathrm{mm}^{2}\end{array}$} \\
\hline & $\mathrm{MPa}$ & $\mathrm{kgf} / \mathrm{mm}^{2}$ & \\
\hline $80 \mathrm{~A}$ & 398,7 & 40,65 & \\
\hline $100 \mathrm{~A}$ & 393,9 & 40,17 & 40,61 \\
\hline $120 \mathrm{~A}$ & 402,3 & 41,03 & \\
\hline
\end{tabular}

Hasil pengelasan TIG pada bahan baja karbon rendah mengunakan filler ER 309L diameter 1,2 $\mathrm{mm}$ didapatkan kuat tarik tertingi pada kuat arus 120A dengan kuat tarik sambungan sebesar 41,03 $\mathrm{kgf} / \mathrm{mm}^{2}$. Sedangkan kuat tarik terendah 
pada kuat arus 100 A dengan kuat tarik sambungan las sebesar 40,17 kgf/mm².

Tabel 6. Data Hasil Uji Tarik hasil pengelasan (Diameter filler $\varnothing$ $1,6 \mathrm{~mm})$

\begin{tabular}{|c|c|c|c|}
\hline \multirow{2}{*}{$\begin{array}{l}\text { Kuat } \\
\text { Arus }\end{array}$} & \multicolumn{2}{|c|}{ Kuat tarik } & \multirow{2}{*}{$\begin{array}{l}\text { Rata - } \\
\text { rata } \\
\mathrm{kgf} / \mathrm{mm}^{2}\end{array}$} \\
\hline & $\mathrm{MPa}$ & $\mathrm{kgf} / \mathrm{mm}^{2}$ & \\
\hline $80 \mathrm{~A}$ & 395,5 & 40,33 & \\
\hline $100 \mathrm{~A}$ & 394,9 & 40,26 & 40,77 \\
\hline $120 \mathrm{~A}$ & 409,40 & 41,74 & \\
\hline
\end{tabular}

Dalam pengelasan spesimen mengunakan diameter filler $1,6 \mathrm{~mm}$ didapatkan kuat tarik sambungan terbesar pada kuat arus 120 A dengan kuat tarik sambungan sebesar $41,74 \mathrm{kgf} / \mathrm{mm}^{2}$ dan didapatkan kuat tarik terendah pada kuat arus 100 A dengan kuat tarik sambungan sebesar 40,26 kgf/ $/ \mathrm{mm}^{2}$.

Tabel 7. Data Hasil Uji Tarik hasil pengelasan (Diameter filler $\varnothing$ 2,0 $\mathrm{mm}$ )

\begin{tabular}{|c|c|c|c|}
\hline \multirow{2}{*}{$\begin{array}{c}\text { Kuat } \\
\text { Arus }\end{array}$} & \multicolumn{2}{|c|}{ Kuat tarik } & \multirow{2}{*}{$\begin{array}{c}\text { Rata - } \\
\text { rata } \\
\mathrm{nga} / \mathrm{mm}^{2}\end{array}$} \\
\hline $80 \mathrm{~A}$ & 398,2 & 40,6 & \\
\hline $100 \mathrm{~A}$ & 402,0 & 41,00 & 40,43 \\
\hline $120 \mathrm{~A}$ & 389,40 & 39,71 & \\
\hline
\end{tabular}

Hasil pengelasan TIG pada baja karbon rendah dengan mengunakan filler dengan diameter 2,0 $\mathrm{mm}$ didapatkan kuat tarik sambungan terbesar pada kuat arus 100 A dengan kuat tarik sambungan 41,00 $\mathrm{kgf} / \mathrm{mm}$ dan kuat tarik sambungan terendah pada kuat arus 120 A dengan kuat tarik sambungan sebesar $39,71 \mathrm{kgf} / \mathrm{mm}^{2}$.

Tabel 8. Data Hasil Uji Tarik hasil pengelasan (Diameter filler $\varnothing 2.4$ $\mathrm{mm}$ )

\begin{tabular}{|c|c|c|c|}
\hline \multirow{2}{*}{$\begin{array}{l}\text { Kuat } \\
\text { Arus }\end{array}$} & \multicolumn{2}{|c|}{ Kuat tarik } & \multirow{2}{*}{$\begin{array}{c}\text { Rata - } \\
\mathrm{rata} \\
\mathrm{kgf} / \mathrm{mm}^{2}\end{array}$} \\
\hline & $\mathrm{MPa}$ & $\mathrm{kgf} / \mathrm{mm}^{2}$ & \\
\hline $80 \mathrm{~A}$ & 389,5 & 39,72 & \\
\hline $100 \mathrm{~A}$ & 402,0 & 41,00 & 40,67 \\
\hline $120 \mathrm{~A}$ & 404,9 & 41,29 & \\
\hline
\end{tabular}

Hasil pengelasan TIG pada baja karbon rendah dengan mengunakan filler dengan diameter 2,4 mm didapatkan kuat tarik sambungan terbesar pada kuat arus 120 A dengan kuat tarik sambungan 41,29 $\mathrm{kgf} / \mathrm{mm}$ dan kuat tarik sambungan terendah pada kuat arus 90 A dengan kuat tarik sambungan sebesar 39,72 $\mathrm{kgf} / \mathrm{mm}^{2}$. Didapatkan rata-rata kuat tarik sambungan sebesar 40,67 kgf/mm².

Kuat tarik sambungan tertinggi di tiap-tiap pengelasan terdapat pada kuat arus 120 A dengan dimenggunakan diameter filler 1,6 $\mathrm{mm}$ yaitu sebesar 41,74 $\mathrm{kgf} / \mathrm{mm}^{2}$. Sedangkan kuat tarik bahan terendah ditunjukkan pada proses pengelasan menggunakan diameter filler 2,0 mm pada kuat arus 120A dengan kuat tarik sambungan sebesar $39,71 \mathrm{kgf} / \mathrm{mm}^{2}$.

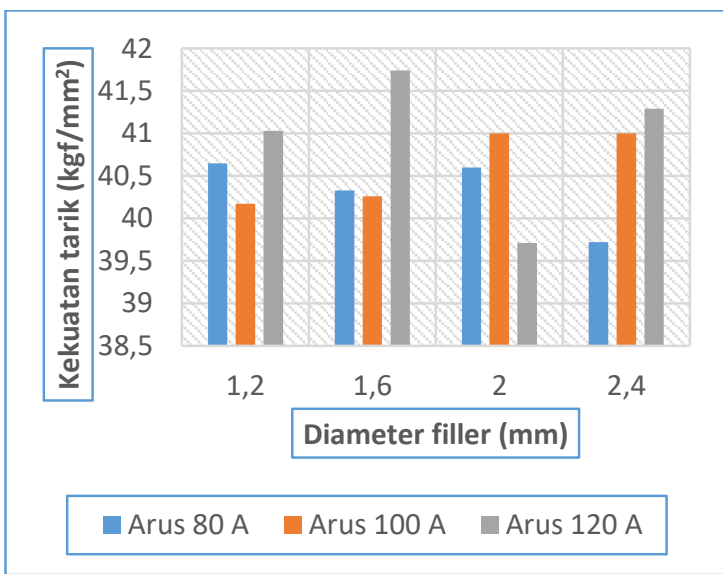

Gambar 4. Grafik perbandingan hasil uji tarik pada setiap spesimen

Hasil rata-rata kuat tarik sambungan las didapatkan $40,6 \mathrm{kgf} / \mathrm{mm}^{2}$ lebih tinggi dari pada kuat tarik bahan sebesar 36,37 $\mathrm{kgf} / \mathrm{mm}^{2}$.

Uji struktur mikro pada daerah HAZ pada spesimen dilakukan untuk mempresentasikan struktur mikro yang terbentuk akibat pengelasan. 


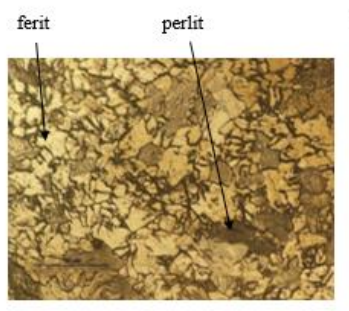

(a)

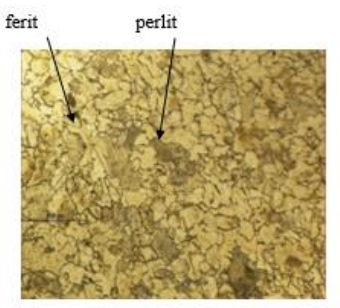

(b)

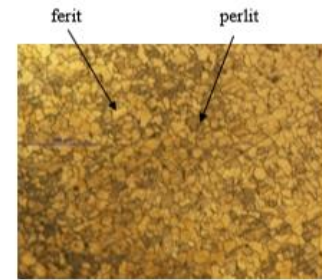

(c)
Gambar 5. Foto struktur mikro daerah HAZ (Diameter filler $\varnothing 1,6 \mathrm{~mm}$ ) kuat arus 80A (a), 100A (b), 120A (c) dengan pembesaran $200 x$

Analisa foto struktur mikro pada titik HAZ pada gambar 5 didominasi butiran ferit dan perlit dimana berbentuk pipih abuabu dan hitam yang tersebar di setiap area. Struktur tersebut dapat terbentuk akibat pendinginan udara. Nampak terlihat jelas perubahan bentuk dan ukuran ferit pada setiap kenaikan arus dalam peroses pengelasan disebabkan karena semakin besar arus yang diterima semakin besar panas yang diterima (head imput). Dari gambar tersebut terlihat adanya daerah terdampak panas di daerah HAZ dengan ukuran ferit terlihat semakin mengecil di setiap kenaikan arus pengelasan.

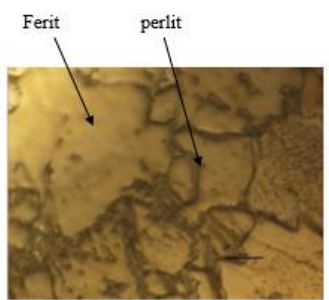

(a)

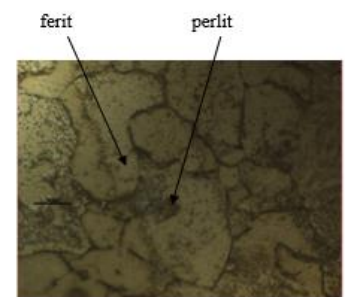

(b)

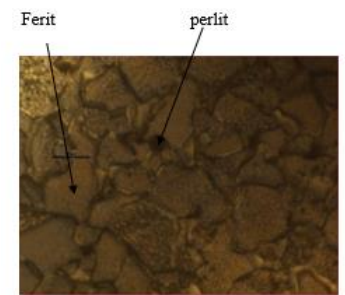

(c)

Gambar 6. Foto struktur mikro daerah HAZ (Diameter filler $\varnothing 1,6 \mathrm{~mm}$, kuat arus 80A (a), 100A (b), 120 (c) dengan pembesaran 1000x)

Dari gambar di atas menunjukan terjadinya perubahan butiran ferit dan jumlah ferit di setiap kenaikan arus. Dibuktikan dengan jumlah ferit pada gambar 6.a berjumlah 32 butiran ferit yang tersebar di area titik HAZ pada arus pengelasan $80 \mathrm{~A}$ dan meningkat menjadi 36 butiran ferit pada titik HAZ dengan kuat arus 100 A pada gambar 6.b. Pada gambar 6.c menunjukan adanya peningkatan jumlah butiran ferit di area titik HAZ dengan kuat arus 120 A dengan jumlah 49 butiran ferit. Dengan semakin meningkatnnya jumlah butiran ferit dan mengecilnya ukuran butiran ferit, menyebabkan terjadinya peningkatan susunan butiran perlit di area HAZ yang mempengaruhi kekuatan mekanik sambungan las.

Pada pengujian struktur mikro hasil pengelasan, analisa dilanjutkan pada titik HAZ pada sambungan las yang mengunakan diameter filler $\varnothing 1,6 \mathrm{~mm}$ dengan kuat arus 80A, 100A, dan 120A. Terjadi peningkatan jumlah butiran ferit dan mengecilnya butiran ferit di area HAZ ditiap kenaikan arus dalam pengelasan disebabkan banyaknya panas yang diserap oleh bahan (head imput). Pendinginan mengunakan angin menyebabkan 
banyaknya butiran perlit yang mempengarui sifat mekanik logam pada daerah HAZ.

\section{Kesimpulan}

Berdasarkan beberapa pengujian yang telah dilakukan, maka dapat disimpulkan :

1. Pada proses pengelasan baja karbon rendah ST 37 ketebalan $3 \mathrm{~mm}$ dengan menggunakan proses pengelasan TIG danfiller ER $309 \mathrm{~L}$ pada kuat arus pengelasan $80 \mathrm{~A}, 100 \mathrm{~A}$ dan $120 \mathrm{~A}$ di hasilkan kualitas sambungan yang cukup baik. Dari pengujian tarik sambungan las maka dapat disimpulkan bahwa untuk kuat tarik sambungan las tertinggi sebesar $41,74 \mathrm{~N} / \mathrm{mm}^{2}$ didapatkan pada pengelasan dengan diameter filler 1,6 mm pada kuat arus pengelasan 120A. Sedangkat kuat tarik terendah sebesar 39,71 $\mathrm{kgf} / \mathrm{mm}^{2}$ pada pengelasan mengunakan diameter filler 2,0 mm dengan kuat arus $120 \mathrm{~A}$.

2. Untuk pengujian struktur mikro terdapat perubahan ukuran dan jumlah ferit di daerah HAZ pada proses pengelasan mengunakan diameter filler 1,6 $\mathrm{mm}$ dengan kuat arus 80 A,100 A dan 120 A. Dimana semakin besar arus pengelasan yang dipakai, semakin besar panas yang diberikan dan yang diserap oleh bahan yang sangat mempengarui ukuran dan jumlah ferit pada daerah HAZ.

\section{Daftar Pustaka}

[1]. Ninien, S., \& Ponimin, P. (2012).
Analisa
Pengaruh
Penggunaan
Variasi
Besaran Arus Pada Las TIG
Terhadap Perubahan
Struktur
Mikro. MeTrik, 5(01), 18

[2]. Romli, R. (2012). PENGARUH

PROSES PENGELASAN

TIG TERHADAP SIFAT
MEKANIS

BAHAN

PADUAN

ALUMINIUM. AUSTENIT, $4(01$.

[3]. Djamiko, Riswan Dwi. 2008. Teori Pengelasan Logam. Jurusan Pendidikan Teknik Mesin Fakultas Teknik Universitas Negeri Yogyakarta.

[4]. Daryanto, 2011, Teknik Mengelas Logam, Sarana Tutorial Nurani Sejahtera, Bandung.

[5]. Dadang. 2013. Teknik Las GTAW. Kementrian Kebudayaan dan Pendidikan Republik Indonesa. 